\title{
Comment
}

\section{THE VALIDITY OF ARBITRATION PROVISIONS IN TRUST INSTRUMENTS}

Recent years have revealed a dramatic increase in the attention that the business and legal communities have given to trust arrangements as a means of providing effective financial and estate planning. The trust device offers many advantages, not the least of which is the opportunity it provides for the protection of personal wealth through the stewardship of a trustee well versed in matters of financial management. However, a trust arrangement may create more problems than it solves. In particular, the courts have been quite chary of permitting deviations from or modifications of the express terms of the trust instrument-even where it seemed highly probable that the settlor would have preferred the change. ${ }^{1}$ The financial adviser or estate planner must also consider the complex jurisdictional problems which can arise in connection with the judicial settlement of a trust dispute, particularly when the controversy involves indispensable parties beyond the reach of the court's process. ${ }^{2}$

Trust disputes may be resolved with greater speed and economy if the trust instrument provides for the submission of disputes to arbitration. Substituting arbitration for the lethargic and ponderous, albeit customary, method of judicial settlement offers many other advantages. The arbitrators need not be bound by "mere dry principles of law"3 but may follow the substantive and procedural rules contained in their submission. If the trust instrument provides for the equivalent of nation-wide reach of process, the arbitrators will not be confronted with the jurisdictional problem noted above. ${ }^{4}$ The terms of the trust instrument may also stipulate conditions under which the distributive provisions may be modified or the trust terminated. ${ }^{5}$ Coupled with an arbitration clause, a power of amendment may provide a source of flexibility sufficient to permit the trust provisions to keep abreast of the changing needs of the beneficiaries. In addition, an arbitration provision can materially lessen the burdens of trust administration by providing the trustee with a means of mini-

${ }^{1}$ See Stanton v. Wells Fargo Bank \& Union Trust Co., 150 Cal. App. 2d 763, 770, 310 P.2d 1010, 1015 (1957).

2 See, e.g., Hanson v. Denckla, 357 U.S. 235 (1958).

32 J. STORX, EQUTTY JURISPRUdENCE $\$ 1454$ (13th ed. 1886).

4 Cf. National Equip. Rental, Ltd. v. Szukhent, 375 U.S. 311 (1964).

5 Unless the terms of the trust instrument provide otherwise, a court (and hence an arbitrator) may modify only the administrative provisions of the trust. See, e.g., Claflin v. Clafin, 149 Mass. 19, 20 N.E. 454 (1889); Restatedrent (Second) of Trusts $\$ 337$ (1959). See text accompanying notes 6,79 infra. 
mizing the costs, delays and complexities associated with formal adjudication. The efficacy of such an arrangement will, at the outset, depend upon how it is received by the judiciary.

Viewed as a substitute for court adjudication, arbitration cannot be considered a panacea. Controversies beyond a court's power to decide will fare no better before an arbitrator. ${ }^{8}$ Arbitration cannot be placed in proper prospective unless it is viewed as one among several available devices designed to foster flexibility and ease of administration. ${ }^{7}$

What limited authority there is indicates that in considering arbitration clauses the courts have been concerned with both the fiduciary relationship existing between the trustee and the cestui que trust and "ouster" of equity or probate court jurisdiction. ${ }^{8}$ Because of the paucity of cases dealing directly with the validity of arbitration in trust disputes, it is necessary to observe courts' responses in closely analogous situations. This Comment will explore the legal roadblocks confronting those who may find it advantageous to insert arbitration provisions in trust instruments and will suggest means to maximize the advantages of arbitration in practice.

I

\section{ARBITRATION INVOLVING FIDUCIARIES}

In his grandiloquent manner, Judge Cardozo handed down the classic statement of a fiduciary's duty in Meinhard $v$. Salmon.

Many forms of conduct permissible in a workaday world for those acting at arm's length, are forbidden to those bound by fiduciary ties. A trustee is held to something stricter than the morals of the marketplace. Not honesty alone, but the punctilio of an honor the most sensitive, is then the standard of behavior. . . ${ }^{10}$

\section{A. Historical Background}

At early English common law an executor or administrator could submit to arbitration virtually any controversy concerning the estate he

'A court, under the Claflin doctrine, is powerless to order a modification of the administrative provisions of a trust unless all the beneficiaries are sui juris and consent to the change. Claflin v. Clafiin, 149 Mass. 19, 20 N.E. 454 (1889). All present and future interests must be adequately represented or the court will not proceed. See, e.g., Mabry v. Scott, 51 Cal. App. 2d 245, 124 P.2d 659, cert. denied, 317 U.S. 670 (1942).

7 A measure of flexibility may also be achieved through a power of appointment in the trustee.

8 See, e.g., In re Fales' Will, 22 Misc. $2 \mathrm{~d}$ 68, 195 N.Y.S.2d 466 (Sur. Ct. 1960). See note 52 infra.

9 249 N.Y. 458, 164 N.E. 545 (1929); accord, Smith v. Tolversen, 190 Minn. 410, 252 N.W. 423 (1934).

10249 N.Y. at 464,164 N.E. at 546. 
represented. ${ }^{11}$ This authority was implied from his power to settle, release, abandon or compromise all claims by or against the estate. ${ }^{12} \mathrm{How}-$ ever, at law he would be chargeable with a devastavit if the estate were injured..$^{13}$ At equity, on the other hand, the personal representative would not be chargeable with a devastavit if he acted without negligence and in good faith for the benefit of the estate. ${ }^{14}$ The rule of equity has predominated in America. ${ }^{15}$

Early in its history, arbitration was expressly authorized by statute. The first English statute codifying the common law of arbitration was enacted in $1698 .^{16}$ In 1893 the Trustee Act ${ }^{17}$ was enacted and put into statutory form the common law rule permitting trustees to submit claims in favor of or against the trust estate to arbitration. The Trustee Act of $1925^{18}$ somewhat broadened the scope of arbitrability of trust disputes by giving the trustees the authority to "submit to arbitration . . . any debt, account, claim, or thing whatever relating . . . to the trust."19

Statutes in several jurisdictions in the United States expressly authorize personal representatives and other fiduciaries to submit disputes concerning their estates or trusts to arbitration. ${ }^{20}$ The Restatement takes the position that a trustee may submit any claims which he holds as trustee $^{21}$ and any claims against him which, if successful, would result in

11 H. Godefror, Trusts \& Trustees 249-50 (5th ed. 1927); W. Rolitson, Witus § 261, at 484 (1939).

12 W. Routrson, Wuis § 261, at 484 (1939).

13 Wheatly v. Martin's Adm'r, 6 Leigh 62 (Va. 1835); Brightman v. Keighley, 78 Eng. Rep. 307 (C. P. 1585). A devastavit occurred whenever an executor or administrator wasted the assets of the estate in his charge. W. RounIson, WIIIS \$ 258, at 479 (1939).

14 See, e.g., Pennington v. Healey, 149 Eng. Rep. 455 (Ex. 1833); Blue v. Marshall, 24 Eng. Rep. 1110 (Ch. 1735).

15 See Berry v. Parkes, 3 S. \& M. 625 (Miss. 1844).

10 An Act for Determining Differences by Arbitration of 1698, 9 \& 10 Will. 3, c. 15.

17 Trustee Act of 1893, 51 \& 52 Vict. c. 59, discussed in J. Redman, Arbitration aNd AWARDS 18 (4th ed. 1903).

18 Trustee Act of 1925, 15 \& 16 Geo. 5, c. 19, discussed in F. Russedx, Arbitration 22 (17th ed. 1963).

19 Trustee Act of $1925,15 \& 16$ Geo. 5, c. $19,815$.

20 The state statutes authorizing arbitration by executors, administrators and trustees may be grouped in two categories: those which make court approval of the submission a condition precedent to the validity of the award, ARIZ. REv. STAT. ANN. § 12-1508 (1956); Conn. Gen. Stat. Ann. \& 45-232 (1958); W. Va. Code AnN. § 55-10-7 (Supp. 1966), and those which do not require prior court approval, ARK. Stat. ANn. § 34-505 (1947); GA. Code Ann. § 7-103 (1935); Ky. Rev. Stat. § 417.014 (1962); Tenn. Code Ann. § 23-503 (1955); VA. CODE ANN. \& 8-507 (1950). Other states have only a general arbitration statute authorizing arbitration of any "controversy." See, e.g., CAI. CoDE Crv. PRoc. $\S 1281$ (West Supp. 1966).

21 Restateacent (Second) of Trusts \& 192, comment a (1959). 
a diminution of the trust estate ${ }^{22}$ provided that in so doing he exercises "reasonable prudence."

\section{B. Arbitrability of Disputes Between Trustee and Cestui Que Trust}

The cases involving the arbitrability of disputes concerning trusts or decedent's estates have, almost without exception, arisen in situations where one of the disputants is a third party, not privy to the fiduciary relationship existing between the trustee or personal representative and the cestui or distributee. ${ }^{24}$ However, the few cases in which a court has been squarely confronted with a dispute between trustee and cestui indicate a somewhat tolerant attitude toward arbitration.

\section{Arbitration Based on Agreement of the Parties}

Apparently, the question of the arbitrability of disputes between trustee and cestui was first considered in England in Auriol v. Smith. ${ }^{25}$ The central question before the court was whether the award which had been made a rule of the court ${ }^{26}$ by consent of the parties could be set aside after the statute of hmitations had run. Also at issue was the effect upon the award of the trustee's fraudulent concealment of certain matters from the arbitrator. The court held that the award could not be set aside and, in response to a cliallenge to the propriety of arbitration between parties to a fiduciary relationship, the Lord Chancellor stated that "the trustee and cestui que trust going to arbitration, put one another at arm's length like other parties . ... ."27 This statement constitutes some authority for the general proposition that disputes between trustee and cestui are arbitrable, but it is doubtful whether an American court would find that the trustee abandons his fiduciary obligations during the arbitration proceeding and deals at arm's length..$^{28}$ There appears to be no persuasive reason for relieving the trustee of his duty of full disclosure

22 Id. $\S 192$, comment $b$.

23 Id. § 192.

24 See, e.g., Brower v. Osterhout, 7 W. \& S. 344 (Pa. 1844) (trustee submitted dispute concerning boundary of trust property to arbitration). The Restatement is also concerned with this type of situation. Restatenant (SECOND) of Trusts $\$ 192$ (1959).

2537 Eng. Rep. 1041 (Ch. 1823), discussed in J. CatdWeIr, Arbitratron 197 (2d ed. 1825) and J. Hrte, Trustees 822-23 (4th ed. 1867); cf. Ward v. Periam, 22 Eng. Rep. 78 (Ch. 1720).

26 An Act for Determining Differences by Arbitration of 1698, 9 \& 10 Will. 3, c. 15, provided that the parties could agree in the submission agreement that the award would be made a rule of court and hence binding upon the parties as would be any other court decision.

$2 \pi 37$ Eng. Rep. at 1045.

28 Cf. In re Fales' Will, 22 Misc. 2d 68, 195 N.Y.S.2d 466 (Sur. Ct. 1960) (reserving the power to pass de novo on the question of breach of fiduciary duty by trustee); Fidehity Trust Co. v. Butler, $28 \mathrm{Ky}$. L. Rptr. 1268, 91 S.W. 676 (1906) (the least overreaching by guardian will vitiate the award). 
by allowing him to assume an adversary posture toward his cestui. ${ }^{29}$ It seems reasonable to conclude that American courts will adopt a more moderate position and set aside awards in circumstances where they would deny binding effect to a prior trust proceeding in court; that is, where the decision was the product of the trustee's fraud, ${ }^{30}$ failure to disclose $^{31}$ or other inequitable conduct.

The earliest American case involving the arbitration of a trust dispute appears to be Turk $v$. Turk. ${ }^{22}$ Theodore Turk, a devisee of the testator, took control of certain property and held it in trust for the benefit of his co-devisees and himself. After several years the parties agreed to submit a dispute concerning the distribution of the property to arbitration. An award followed and William Turk, an heir of one of the original parties to the arbitration, sought to have it set aside. The question before the court was whether a cross bill in equity was a suffcient pleading to set up the award as a bar to the action. ${ }^{33}$ In finding that it was sufficient, ${ }^{34}$ the court implicitly upheld the validity of arbitration between an inter vivos trustee and his cestuis que trustent. In both Auriol and Turk the parties to the arbitration agreed among themselves to submit their dispute to arbitration. In the section that follows, the duty or authority ${ }^{35}$ to arbitrate originates in the trust instrument. This distinction becomes important when a party to the arbitration seeks to bind the interests of minor or absent cestuis by the determinations of the arbitrators.

\section{Arbitration Based on Provisions of the Trust Instrument}

The law concerning the validity of arbitration provisions in trust instruments has been more thoughtfully considered. The distinguishing characteristic of sucli provisions is that the interests given by the testator or settlor are conditioned by the terms of his will or conveyance. Those who wisl to take under the instrument are obliged to submit all disputes thereafter arising to arbitration. ${ }^{36}$ In the only case which has involved an arbitration award arising out of a dispute between the tes-

29 Arbitration proceedings are customarily informal. The absence of discovery procedures and the confidential relationship between the parties amplify the need for fair dealing and full disclosure.

302 A. Scotr, Trusts $\$ 220$ (2d ed. 1956).

31 In re Enger's Will, 225 Minn. 229, 30 N.W.2d 694 (1948) (trustee's accounting not res judicata as to issues he did not disclose).

32 3 Ga. 422 (1847).

33 Id. at 423 .

$34 \mathrm{Id}$, at 426 .

35 In setting up a trust, the settlor may make the arbitration provision either obligatory or discretionary on the part of the trustee or cestuis.

38 See Zack, Arbitration: Step-child of Wills and Estates, 11 ARB. J. (n.s.) 179, 191 (1956). 
tamentary trustee and his cestui, the court found the testator's power to bind his devisees in his power to confer an absolute power of appointment upon a third party. ${ }^{37} \mathrm{~A}$ more serious problem arises when the trustee represents both his cestui's and his own interests before the arbitrators. This writer has discovered only one case deahing with such a conflict of interest in the context of a testamentary trust. ${ }^{38}$ Holding that a trustee could not represent his cestui when he had an adverse interest, the court set aside the award. The language of the opinion, however, suggests that the result might have been different if the cestui had been sui juris or represented by either an independent guardian ad litem or next friend. ${ }^{39}$

\section{Disputes Between Guardian and Ward}

Guardians are held to a strict fiduciary standard of loyalty and good faith in every aspect of their dealings with their wards. ${ }^{40}$ The reported cases in which the vahdity of an arbitration award settling a dispute between them has been questioned invariably have involved the adequacy of the ward's representation when his interests are championed by a guardian with an adverse interest in the subject matter of the dispute. ${ }^{41}$ Although the effect of the fiduciary relationship has passed sub silentio, the courts have uniformly refused to permit an interested guardian to represent both his ward's and his own interests simultaneously. Whether

${ }^{37}$ In re Phillip's Estate, $10 \mathrm{~Pa}$. County Ct. 374 (1891).

38 DeVaughn v. McLeroy, 82 Ga. 687, 10 S.E. 211 (1889); cf. Potter v. Moran, 239 Cal. App. 2d 873, 49 Cal. Rptr. 229 (1966) (accounting is not binding unless cestui is represented by independent counsel).

$3982 \mathrm{Ga}$. at 699,10 S.E. at 214 . The requirement that the beneficiary be represented by someone without an adverse interest may rest upon a constitutional base. See, e.g., Hansberry v. Lee, 311 U.S. 32 (1940) (representation in a class action by a party with an interest adverse to other members of the class is a demial of due process). In analogous situations involving arbitration of disputes between guardian and ward, the courts have consistently invahdated awards which were the product of inadequate representation of the ward's interests. See, e.g., DeVaughn v. McLeroy, supra; Poullain v. Poullain, 79 Ga. 11, 4 S.E. 81 (1887) ; Fortune v. Killebrew, 86 Tex. 172, 235 S.W. 976 (1873). One commentator has succinctly summarized the rule as follows: "[I]t is clear that the ward will not be concluded or bound by a submission [to arbitration] of a matter in controversy between the guardian and the ward, where the guardian acts for himself and also as guardian for the ward in the submission." W. Sturges, Contmerctal Arbitrations aNd Awards 57 (1930). But see Overby v. Thrasher, $47 \mathrm{Ga} .11$ (1872) (when the arbitration takes place upon the termination of the guardian-ward relationship, the parties deal at arm's length).

40 See Overby v. Thrasher, 47 Ga. 11 (1872); Fidehty Trust Co. v. Butler, $28 \mathrm{Ky}$. L. Rptr. 1268, 91 S.W. 676 (1906).

41 An award rendered under such circumstances is defective; bowever, the authorities differ as to whether such imperfect representation of the ward's interests causes the award to fail at the outset or whether it becomes voidable at the instance of the ward when he reaches majority. See, e.g., DeVaughn v. McLeroy, 82 Ga. 687, 10 S.E. 211 (1889) (void); Poullain v. Poullain, 79 Ga. 11, 4 S.E. 81 (1887) (void); Fortune v. Killebrew, 86 Tex. 172, 235 S.W. 976 (1873) (voidable); J. Caldwele, Arbitration 11 (2d ed. 1825) (voidable). 
such inadequate representation causes a failure of jurisdiction, as stated by one court, ${ }^{42}$ or whether it results in a denial of due process, ${ }^{43}$ the effect is not the same-the award is invahid.

\section{Disputes Between Husband and Wife Concerning Their Children}

Arbitration of trust disputes and arbitration of disputes between a former husband and wife concerning their offspring involve many of the same considerations. During their nuarriage husband and wife cannot deal at arni's length. ${ }^{44}$ While the dissolution of the marriage may diminish the intensity of their fiduciary relationship, ${ }^{45}$ the parents may not deal at arm's length where the welfare of their children is concerned.

In $1964 \mathrm{New}$ York clarified its law relating to the validity of arbitration agreements incident to a niarriage settlement. In Sheets v. Sheets ${ }^{40}$ the parties had nutually agreed to arbitrate all disputes concerning custody, visitation rights and education. The court rejected the assertion that such agreements were invalid per se, holding that a court could set aside the resulting award only upon a showing that it adversely affected ${ }^{47}$ the "substantial" best interests of the child. ${ }^{48}$ This disposition of the case is a tenable one, which avoids an abdication of the court's responsibility as parens patriae ${ }^{49}$ while recognizing that the parties should be free to submit their disputes to a tribunal of their own choosing. The reasoning of the opinion is hikewise sound and should provide a workable standard when applied to arbitration awards in trust disputes. The court recognized that as long as the best interests of the child were ensured protection through an omnipresent judicial check," arbitration "should be encouraged as a sound and practical method"51 for resolving intrafamily disputes. This reasoning seems equally applicable to trust arbitration where the cestui que trust is not sui juris.

\section{II}

OUSTER OF PROBATE OR EQUITY COURT JURISDICTION

Aside fron the difficulties engendered by the fiduciary relationship between trustee and cestui, the validity of an arbitration clause may be

42 DeVaughn v. McLeroy, 82 Ga. 687, 699, 10 S.E. 211, 214 (1889).

43 See, e.g., Hansberry v. Lee, 311 U.S. 32 (1940) (representation in a class action by a party with an interest adverse to other members of the class is a denial of due process).

443 J. POMERoY, EQUTTY JURISPRUdence $\S 962 \mathrm{~b}$, at 853-54 (5th ed. 1941).

45 See 3 J. POACERox, EqUTTY JURISpRUdence § 961a, at 843-45 (5th ed. 1941).

4022 App. Div. 2d 176, 254 N.Y.S.2d 320 (1964).

47 Id. at 179,254 N.Y.S.2d at 324.

48 Id. at $178-79,254$ N.Y.S.2d at 324.

49 Id. at 178,254 N.Y.S.2d at 324 .

60 Id. See discussion of judicial standard of review in part III infra.

61 Id. at 179-80, 254 N.Y.S.2d at 325. 
jeopardized because, by its very nature, it seeks to avoid formal court action. Although historically the courts have been jealous of their jurisdiction, ${ }^{52}$ they have gradually relinquished some of their control over wills containing arbitration provisions..$^{53}$

\section{A. Will Provisions Requiring Disputes to be Submitted to Arbitration}

Concern over "ouster" of court jurisdiction has most frequently arisen in wills disputes where the testator has included a mandatory arbitration clause in his will. At first courts were hostile to the concept of arbitration, ${ }^{54}$ and will provisions requiring it were unceremoniously invalidated. ${ }^{55}$ There was, however, an inherent inconsistency in this reaction. The avowed purpose of the probate courts has been to give voice to the testator's intent..$^{56}$ Thus, if the testator expressed his intention with sufficient clarity, the courts were bound to expedite it unless the execution of the testator's wishes would contravene some positive law or public policy. ${ }^{57}$ The courts apparently have not found arbitration to be against public policy, and the current majority rule seems to be that such will provisions are valid.58

A more substantial objection to arbitration as a means of deciding

52 As a general rule, probate courts have jurisdiction over wills and testamentary trusts while superior courts in the exercise of their equitable jurisdiction supervise inter vivos trusts. See, e.g., Taylor v. McClave, 128 N.J. Eq. 109, 113, 15 A.2d 213, 216 (1940) (equity has jurisdiction over trusts and wills to the extent that they create trusts).

53 Zack, Arbitration: Step-child of Wills and Estates, 11 ARB. J. (n.s.) 179 (1956).

$54 I d$.

55 Phillips v. Bury, 90 Eng. Rep. 198 (Ch. 1695).

56 Zack, supra note 53 , at 179-80.

57 T. Atrnsson, Writs 406, 413-15 (2d ed. 1953).

58 American Bd. of Comm'rs of Foreign Missions v. Ferry, 15 F. 696 (C.C.W.D. Mich. 1883); Wait v. Huntington, 40 Conn. 9 (1873); Nations v. Ulmer, 139 S.W.2d 352 (Tex. Civ. App. 1940). But see Talledega College v. Callanan, 197 Iowa 556, 197 N.W. 635 (1924).

The cases in which arbitration of will controversies has been challenged appear to fall into two broad categories: those in which the named arbitrator is also the personal representative and a legatee, devisee or distributee, and those in which the named arbitrator is an independent party. In both situations the courts have vindicated the will provision, usually by analogy to contract law. American Bd., supra at 699-700; Moore v. Harper, 27 W. Va. 362, 373-74 (1886).

The American Board court clearly recognized that the residuary legatee qua arbitrator could swell the residuum in the course of his determination of the amount due to the legatees. In response to the contention that one cannot judge his own case, the court found that: "It is enough to say that it [the maxim] has never been understood as an inhibition upon the rights of individuals to select their own tribunals provided they do so with a full knowledge of all the facts ...."15 F. at 701 .

In Moore the court held that a bequest or devise was subject to the same principles as an inter vivos gift in the sense that both may be restricted or conditioned according to the pleasure of the testator or donor. $27 \mathrm{~W}$. Va. at 374 ; accord, Wait v. Huntington, sitpra. 
will controversies has been noted by some courts. Probate proceedings are in rem and hence binding on all persons having adequate notice, whether or not they actually participate in the proceeding. ${ }^{59}$ Invalidating an agreement between several contestants to submit their will dispute to arbitration, the Supreme Court of California ${ }^{60}$ observed that it would be unfair to allow a few parties claiming to be beneficiaries to foreclose the rights of all those who might have an interest in the subject matter of the controversy but who were not parties to the arbitration proceeding. ${ }^{61}$ The court does not indicate whether the same objection would exist if the will itself had authorized or required arbitration. However, the majority of courts have not found the in rem nature of probate proceedings to be an obstacle to arbitration of will contests. ${ }^{62}$

\section{B. Arbitration of Disputes After Probate}

Postprobate arbitration agreements between those who take under the will would seem to sidestep the problem of "ouster" of probate jurisdiction. Under such agreements the will would be probated but the settlement of disputes between the parties would be reserved for subsequent determination by the arbitrators. ${ }^{63}$ Withholding a will controversy from adjudication by the probate court seems undesirable from two standpoints. It has the effect of relegating the function of the probate court to that of a mere registration booth to preserve the illusion that the court has not been ousted of its jurisdiction. Perhaps of greater importance to the estate planner, postprobate arbitration agreements promote unnecessary and wasteful duplication of the decisional process. ${ }^{64}$ A more straightforward approach would be to permit the parties to submit their differences to arbitration and to give the court an ultimate supervisory jurisdiction to ensure fairness to all interested parties and adequate representation of their interests.

59 Mullane v. Central Hanover Bank \& Trust Co., 339 U.S. 306 (1950). However, in Mullane the Court refused to characterize the proceeding (a trust accounting) as in rem or in personam. Id. at 312-13. More recent decisions have further undermined the in personamin rem distinction. See, e.g., Hanson v. Denckla, 357 U.S. 235 (1958); Stenens v. Torregano, 192 Cal. App. 2d 105, 13 Cal. Rptr. 604 (1961). It seems probable that the courts will hold arbitration proceedings to compliance with due process standards at least as rigorous as are currently required to give binding effect to a court adjudication.

60 Carpenter v. Bailey, 127 Cal. 582, 60 P. 162 (1900).

$61 \mathrm{Id}$. at 582, 60 P. at 164 (dictum); accord, In re Meredith's Estate, 275 Mich. 278, 266 N.W. 351 (1936).

62 See notes 58 \& 59 supra and accompanying text.

${ }^{63}$ The only case in which such a postprobate agreement has been in issue is In re Johnson, 87 Neb. 375,127 N.W. 133 (1910) (no contest provision in will successfully circumvented).

64 See Zack, supra note 53, at 193. 


\section{III \\ STANDARD OF REVIEW}

If arbitration of disputes is to serve any useful purpose either through expediting determination of the controversy or through reducing the cost of adjudication, it must be accorded some degree of autonomy by the courts.

At the outset it should be noted that the courts have ample power to intervene to promote justice and to protect the interests of all parties. If the arbitrator purports to act beyond the scope of his authority, ${ }^{06}$ or commits a gross error in judgment evincing partiality, corruption or prejudice, ${ }^{66}$ or otherwise abuses his office, a court may intervene and set aside or correct an award so rendered. However, courts have gone further in supervising arbitration between fiduciaries. In In re Fales' Will ${ }^{\text {or }}$ the court reserved the power to decide de novo whether the testamentary trustee had violated the fiduciary duties which the law imposed upon her. ${ }^{68}$ The standard of review applied in this case gives no weight to the factual findings of the arbitrator and, in effect, makes the arbitration proceeding a useless extra step in the determination of the dispute. In Sheets $v$. Sheets ${ }^{69}$ a more moderate standard of review was applied. In that case the court reserved the power to decide the controversy de novo ${ }^{70}$ but conditioned its exercise upon a finding: (1) that the award adversely affected the best interests of the child, and (2) that the interests affected were "substantial." "Since this approach gives appropriate weight to the findings of the arbitrator, it seems clearly preferable to an unconditioned power to review all the determinations made by the arbitrator. Applying the Sheets standard, a court may set aside an award which appears to be fair and equitable on its face if it finds that the best interests of a minor will otherwise be adversely affected.

The judicial determination to review de novo should not depend on whether the duty to submit disputes to arbitration was inherited along with the cestui's interest in the testamentary trust or was ancillary to an inter vivos agreement. Rather, in deciding on a standard of review, the court should look to the nature of the dispute and to the relative positions of the parties with respect to one another. This is what the more progressive courts have attempted to do in reviewing arbitration

${ }^{65}$ American Bd. of Comm'rs of Foreign Missions v. Ferry, 15 F. 696, 700 (C.C.W.D. Mich. 1883).

66 Id.; see also Pray v. Belt, 26 U.S. (1 Peters) 670 (1828).

6722 Misc. 2d 68, 195 N.X.S.2d 466 (Sur. Ct. 1960).

68 Id. at 70, 195 N.Y.S.2d at 468.

6922 App. Div. 2d 176, 254 N.Y.S.2d 320 (1964).

70 Id. at $178-79,254$ N.Y.S.2d at 324.

71 Id. at 179,254 N.Y.S.2d at 325. 
between parties bound by fiduciary ties..$^{72}$ When minors are involved, the court's responsibility as parens patriae is invoked and it is reasonable to expect a close scrutiny of the circumstances surrounding the award. ${ }^{73}$ As the Sheets case indicates, arbitration affecting the interests of those not sui juris will never attain the unassailable finality of arbitration in other areas.

Where an arbitration award concerning a dispute between trustee and cestui que trust is challenged, the court will require a showing that the interests of the cestui have been adequately represented by an independent party performing the functions of a guardian ad litem or next friend. ${ }^{74}$ Any inequitable advantage taken by the trustee or any lack of full disclosure will likewise invite a judicial veto. The court will also require the arbitrators themselves to be free of any conflict of interest. ${ }^{75}$ If none of the above objections appear, courts may be expected to confine the scope of their review.

\section{IV}

\section{ARBITRATION IN PRACTICE}

Submitting disputes to arbitration usually results in a saving of both time and money. In the absence of an enforceable ${ }^{76}$ arbitration clause, a dispute involving an inter vivos trust must be adjudicated in a court of general jurisdiction ${ }^{77}$ and therefore becomes subject to the vicissitudes of calendar arrearages. Arbitration customarily results in a considerable saving to the parties because court and sometimes counsel fees are avoided.

72 See, e.g., Sheets v. Sheets, 22 App. Div. 2d 176, 254 N.Y.S.2d 320 (1964); Fidelity Trust Co. v. Butler, 28 Ky. L. Rptr. 1268, 91 S.W. 676 (1906). But see Auriol v. Smith, 37 Eng. Rep. 1041 (Ch. 1823).

73 Sheets v. Sheets, 22 App. Div. 176, 178, 254 N.Y.S.2d 320, 323 (1964).

74 See note 39 supra and accompanying text.

75 See Hansberry v. Lee, 311 U.S. 32 (1940); Talledega College v. Callanan, 197 Iowa 556,197 N.W. 635 (1924) (question mooted because there was a majority of non-interested arbitrators).

76 State statutes authorizing arbitration typically provide for enforcement of the agreement. See, e.g., CaL. Code Crv. Proc. $\$ 1281$ (West Supp. 1966) (such agreements are irrevocable except on grounds for revocation of any contract). When one party attempts to avoid arbitration, the aggrieved party may petition the court for an order staying the action pending arbitration. See, e.g., CAL. CODE CIv. Proc. \$ 1281.4 (West Supp. 1966). If a party refuses to comply with the terms of the award, it seems reasonable to suppose that the aggrieved party would be entitled to specific performance in any case where specific performance of a contract would be proper.

77 If diversity of citizenship exists or if a federal question is involved, a federal court would also be a proper forum.

The problem of calendar arrearage is a less important consideration when the dispute involves a testamentary trust. In California, the probate court retains jurisdiction over the trust even after final distribution has. occurred. CAI. ProB. CODE $\$ 1120$ (West 1956). 
In the area of trust disputes arbitration has perhaps even greater advantages over the customary process of court adjudication. Settlors desirous of obtaining the federal income tax advantages ${ }^{78}$ of an irrevocable trust have been discouraged by the inflexible legal doctrines which courts have erected with respect to termination ${ }^{70}$ or modification ${ }^{80}$ of such trusts. However, flexibility need not be sacrificed to tax considerations. If the settlor makes clear the purposes his trust is to serve and what change of conditions will permit a change in the trust instrument, a power of amendment in the trustee or some other adult, which expressly ${ }^{81}$ grants the holder of the power authority to order modification or termination, coupled with an arbitration provision should render an irrevocable trust somewhat more flexible and less expensive to administer.

Because the settlor or the parties are free to select those whom they wisl to decide future controversies, arbitrators may be chosen either on the basis of their knowledge in areas most likely to become the subject of dispute or because of their familiarity with the settlor and beneficiaries. ${ }^{82}$ Tluus, the settlor may arrange his gift or devise so that disputes are certam to be decided by those persons he considers best qualified to sit in judgment.

While it appears likely that the courts will uphold arbitration agreements in trust provisions, it is certain that they will demand compliance with the standards of due process embodied in the requirements of adequate representation of the interests of all beneficiaries whether ascer-

78 If the settlor effectively divests himself of dominion and control over the property placed in trust, the income therefrom will be taxed to the cestui. $C f$., Blair v. Commissioner, 300 U.S. 5 (1937). However, a power to revoke or to control the beneficial enjoyment of the trust will cause the tax hability to remain in the grantor. INr. REv. CoDE of 1954, $\S \S 671-78$.

If the settlor, by himself or together with another person, retains the power to "alter, amend, revoke, or terminate" the trust, the trust res will be included in his gross estate for estate tax purposes. INr. Rev. CoDE of 1954, § 2038(a). However, if the power is in a third party (such as an arbitrator) $\S 2038$ does not require the value of the transferred property to be included in the decedent's gross estate. See, e.g., Estate of Hofheimer, 2 T.C. 773, 783 (1943), aff'd on this point, 149 F.2d 733 (2d Cir. 1945).

70 See, e.g., Claflin v. Claflin, 149 Mass. 19, 20 N.E. 454 (1889); RestateMent (SECond) of TRUSTS $\$ 337$ (1959). The Restatement interprets the Clafin doctrine as requiring the consent of all beneficiaries. In addition, all the beneficiaries must be sui juris and the continuance of the trust must not be necessary to carry out a material purpose of the settlor. Restatrament (Second) of Trusts, App. at 548 (1959).

$80 \mathrm{It}$ is frequently stated that restrictive administrative provisions of the trust may not be varied unless "the main purpose of the trust" is threatened. Stanton v. Wells Fargo Bank \& Umion Trust Co., 150 Cal. App. 2d 763, 770, 310 P.2d 1010, 1015 (1957).

81 If the authority to order a modification or termination of the trust is not granted expressly, a possibility exists that the courts will find the exercise of this power exceeds the scope of the arbitrator's authority.

82 However, if the arbitrator is an interested party, a conflict of interest exists and the validity of the award is jeopardized. See authorities cited notes 39 \& 58 supra. 
tained or contingent ${ }^{83}$ and of adequate notice to all interested parties. ${ }^{84}$ In practice, this will require either the arbitrator or those who seek to initiate the arbitration to make certain that notice has been given in a manner reasonably calculated to inform the interested parties of the time, place and subject matter of the controversy. ${ }^{85}$ Further, if the interests of those not before the arbitrators are to be bound by the award, they must be adequately represented. ${ }^{86}$

Arbitration agreements between the trustee and cestui or among beneficiaries which are not provided for in the instrument pose a more difficult problem. It is fundamental contract law that only the parties to an agreement are bound. ${ }^{87}$ It would be grossly unfair to allow less than all the beneficiaries to enter into an agreement which would affect the rights of all the members of the class. The cases ${ }^{88}$ which have permitted trust disputes to be arbitrated by agreement among the parties did not deal with the problem of binding the interests of absent parties. Rather, they were concerned with the effect of the award on the parties themselves. However, the effect in a will contest of an arbitration agreement entered into by less than all the interested parties was considered in Carpenter v. Bailey. ${ }^{89}$ The court invahdated the agreement, finding that "a few individuals claiming to be the heirs cannot, by stipulation, determine such [a] controversy." But even if the award is void as to the absent parties, it may still bind those who participated in the proceeding. ${ }^{91}$ Although there is no authority directly on point, the same results should follow where the subject matter of the dispute involves a trust.

This writer will not attempt to draft a sample arbitration clause because the format and terms of such a clause will vary according to the results desired. ${ }^{92}$ It is important, however, to set out in general

83 See Mabry v. Scott, 51 Cal. App. 2d 245, 124 P.2d 659, cert. denied, 317 U.S. 670 (1942).

84 Cf. Mullane v. Central Hanover Bank \& Trust Co., 399 U.S. 306 (1950).

85 Cf. id. See note 59 supra.

80 See note 39 supra and accompanying text. Adequate representation of absentee beneficiaries would seem to exist if their interests were identical with those of one of the parties (virtual representation) or if the equivalent of a guardian $a d$ litem were appointed to represent their interests.

87 L. StMpson, Contracts $\$ 116$, at 241 (2d ed. 1965).

88 Turk v. Turk, 3 Ga. 422 (1847); Auriol v. Smith, 37 Eng. Rep. 1041 (Ch. 1823).

89127 Cal. 582, 60 P. 162 (1900).

$00 \mathrm{Id}$. at $585,60 \mathrm{P}$. at 163 .

91 Cf. Sheets v. Sheets, 22 App. Div. 2d 176, 178, 254 N.Y.S.2d 320, 323 (1964).

${ }^{92}$ An interesting example of an arbitration clause is found in George Washington's will. Although it is directed at will controversies, it seems equally applicable to testimentary trust disputes. The testator provided: "[M] w will and direction is expressly, that all disputes (if unhappily any should arise) shall be decided by three impartial and 
terms what the arbitration clause should include. The clause must provide for arbitration by impartial and disinterested arbitrators. It should also make explicit the manner in which appropriate representatives are to be selected to represent the interests of all interested parties not sui juris or not before the tribunal. Further, the clause should make clear whether the arbitrators are to decide the dispute in accordance with the law, with broader principles of equity and common sense, or with a set of criteria set out in the trust instrument.

\section{CONCLUSTON}

While the submission of trust disputes to arbitration offers the settlor many advantages, in the last analysis the efficacy of this method of resolving trust disputes will depend upon the standard of review exercised by the courts. A de novo review renders arbitration useless and hence should be reserved for circumstances indicating inadequacy of absentee representation, overreaching by the trustee or fraud or corruption on the part of the arbitrators. A thoroughgoing review would likewise be proper when it appears that a party's interests have not received adequate representation. The more progressive approach is exemplified by Sheets $v$. Sheets. ${ }^{93}$ That court considered the fiduciary relation to be merely one of a number of factors to be weighed in determining whether to review de novo. Both Sheets and In re Fales' Willo4 illustrate that little, except perhaps time, is risked if the award is set aside. ${ }^{25}$ The parties will merely have their dispute settled in another forum, presumably without prejudice to the riglits of either side.

\section{Blaine Covington Janin}

intelligent men, known for their probity and good understanding-two to be chosen by the disputants-each having a choice of one-and the third by these two-which three men thus chosen, shall unfettered by law, or legal constructions, declare their sense of the testator's intention; and such decision is ... to be as binding on the parties as if it had been given in the Supreme Court of the United States." Zack, Arbitration: Stepchild of Wills and Estates, 11 ARB. J. (n.s.) 179, 182 (1956) (emphasis added).

9322 App. Div. 2d 176, 254 N.YS.2d 320 (1964).

${ }^{94} 22$ Misc. 2d 68, 195 N.Y.S.2d 466 (Sur. Ct. 1960).

85 The validity of an arbitration clause in the trust instrument may be tested with no risk whatsoever to the trustee through the use of a petition for instructions to the superior or probate court. In this manner the trustee may have the validity of the clause judicially determined before any action is taken under it. See, e.g., CAL. Prob. Code $\S 1120$ (West 1956). 